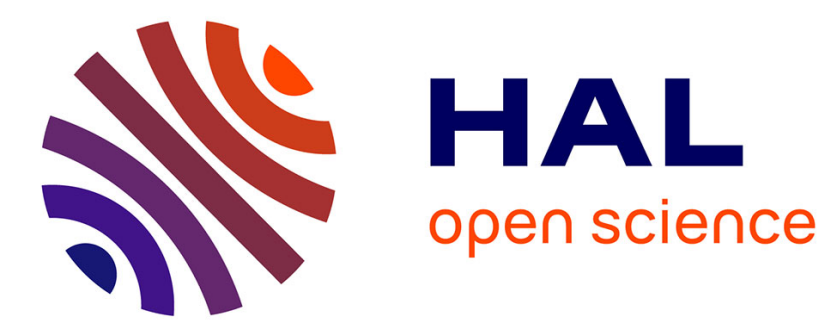

\title{
Comparison between two techniques in laser welding of ceramics
}

\author{
C. Legras, M. Robin
}

\section{To cite this version:}

C. Legras, M. Robin. Comparison between two techniques in laser welding of ceramics. Journal de Physique IV Proceedings, 1994, 04 (C4), pp.C4-189-C4-189. 10.1051/jp4:1994444 . jpa-00252707

\section{HAL Id: jpa-00252707 https://hal.science/jpa-00252707}

Submitted on 1 Jan 1994

HAL is a multi-disciplinary open access archive for the deposit and dissemination of scientific research documents, whether they are published or not. The documents may come from teaching and research institutions in France or abroad, or from public or private research centers.
L'archive ouverte pluridisciplinaire HAL, est destinée au dépôt et à la diffusion de documents scientifiques de niveau recherche, publiés ou non, émanant des établissements d'enseignement et de recherche français ou étrangers, des laboratoires publics ou privés. 


\title{
Comparison between two techniques in laser welding of ceramics
}

\author{
C. LEGRAS and M. ROBIN
}

CALFETMAT, INSA Lyon, Bât. 403, 69621 Villeurbanne cedex, France

Many studies have been conducted on laser interactions with metal and semiconductors, but little has been done in the processing of ceramic with lasers.

The joining of ceramics to themselves can be important for making more complex structures because the size or complexity of the structure renders impractical or impossible a one step processing.

One of the major problems in the fusion welding of ceramics is the control of cracking caused by thermal stresses. A previous solution has been to provide supplementary heating of a broader zone around the weld area with halogen lamps, so that no thermal stresses high enough to cause cracking are reached. However, this heating device suffers mainly from two drawbacks : the space required and the incapacity of measuring any temperature with infrared pyrometer.

In this study, the process has been improved by using uniquely the laser. Therefore, preheating and welding depend on two parameters : power and position of the focal plane. The feasability of such a process has been shown with two types of laser : a $3,5 \mathrm{~kW}$ class $\mathrm{CO} 2$ and a $300 \mathrm{~W}$ class YAG. Since no significant difference in microstructure, vacuum-tight, penetration depth and strength of the weld joint were seen between these two ways, this technique has made laser welding of ceramics more versatile for industrial applications. 